\title{
Family migration and educational outcomes of migrant children in China: the roles of family investments and school quality
}

\author{
Yunsen $\mathrm{Li}^{1} \mathbb{D} \cdot$ Junhui Wang ${ }^{2} \cdot$ Liang Luo $^{3}$
}

Received: 17 October 2019 / Revised: 19 July 2020 / Accepted: 28 July 2020 / Published online: 7 August 2020

(c) Education Research Institute, Seoul National University, Seoul, Korea 2020

\begin{abstract}
This study examines the effects of family migration on migrant children's educational outcomes. We especially focus on the relative importance of family investment and school quality to children's achievements. A unique and nationally representative sample from the National Children's Study of China (NCSC) (2004 migrant children and 3923 rural children) is used. Estimates from the propensity score matching method suggest that conditional on basic personal and family characteristics, children's academic performances are significantly improved by family migration. Further examination using the OaxacaBlinder decomposition approach reveals that over $40 \%$ of the differences in the children's scores in Chinese and about $40 \%$ of those in mathematics can be explained by family investments (about $18.67-21.75 \%$ in different cases) and school quality (about $18-34.67 \%$ in different cases), including parental expectations, family material support, school expenditure, teacher quality, and student-teacher ratio. However, our results also reveal the potential for migrant children to be exposed to social exclusions in urban public schools.
\end{abstract}

Keywords Family migration $\cdot$ Migrant children $\cdot$ Educational outcomes $\cdot$ Family investments $\cdot$ School quality $\cdot$ Oaxacablinder decomposition method

\section{Introduction}

In recent years, family migration has become a mainstream component of rural-urban migration in China. As a result, more and more rural children are becoming migrant children in cities. According to a report from the Ministry of Education of China, the number of migrant children in compulsory education had reached nearly 19 million in 2017 (MOE 2018). Meanwhile, the number of left-behind children dropped to approximately 15 million. Given that about $80 \%$ of migrant children can be admitted to public

Yunsen Li

lysen10384@hotmail.com

1 School of Economics, Southwest University of Political Science and Law, Baosheng Road, Yubei District, Chongqing 401120, China

2 Survey and Research Center for China Households Finance, Southwest University of Finance and Economics, Chengdu 610074, China

3 Collaborative Innovation Center of Assessment Toward Basic Education Quality, Beijing Normal University, Beijing 100875, China schools (Chen et al. 2019), it is possible that most migrant children perform better than their rural counterparts. Lv and Wang (2017) states that compared to left-behind and nonleft-behind rural children in China, migrant children have the most opportunities to complete compulsory school. This finding may imply gaps between the academic performances of rural and migrant children. However, the existing literature of migration mainly focuses on the achievements of left-behind children. As a result, we have little knowledge about the performance of migrant children.

Several reasons can potentially explain the differences in the academic performances of rural and migrant children. First, migrant parents are more educated (Zhao 1999). According to the literature on intergenerational education mobility, the level of the parents' education significantly affects their children's education (Black et al. 2005, 2009). Second, migrant families earn higher incomes by working in cities, and so they are released from the credit constraints of their households, allowing the parents to invest more in their children's education (Davis-Kean 2005; Duncan and Magnuson 2005). Third, as their socioeconomic status improves, migrant families will have higher expectations of their children's education, leading their children to better 
academic performance. Last but not least, migrant children can attend urban public schools, which are of much higher quality than rural public schools. The last three points can also be thought of as the effects of urbanization or migration, especially the family expectation and school characteristics.

However, some recent studies provide contradictory answers as to whether or not migrant children benefit from family migration (Lai et al. 2014; Wang et al. 2017; Chen and Feng 2019). The major problem is that these studies only consider certain specific cities, and thus, the results are not representative. We need representative data to study the development of migrant children.

This study aims to use a representative and national sample to test whether and how family migration influences children's academic performances, including scores in Chinese and mathematics. We pay special attention to the relative importance of family investment and school quality, because they are major changes faced by migrant children. To achieve these goals, the propensity score matching method and Oaxaca-Blinder decomposition approach are employed. Our study will help us identify how family migration affects children's development. In addition, this work provides important evidence for governments, schools, and families about how to implement suitable policies to improve children's performances.

\section{Background and literature review}

As a result of history and institutional problems, there are great gaps between the rural and urban areas of China in almost every aspect, including in areas such as income, education, and medical conditions. Such significant differences have not only privileged urban residents, but have also been the basic force behind rural-urban migration over the past decades. As increasing numbers of rural residents seek jobs in cities, how and why migration affects migrant children's human capital accumulation has been an important issue in China.

The biggest obstacle to the migration of children is the segmented Hukou system in China. Although parental migrations have taken place since the economic reforms and liberalization of China in 1979, the children of migrant parents were not able to attend urban public schools until 1998, when the State Council and Ministry of Public Security jointly issued a tentative policy for migrant children's being able to attend such schools on a temporary basis. However, the tuitions were quite high and the procedures for admission were very complicated, resulting in the exclusion of most migrant children from urban public schools. Big change happened in 2001 when the State Council of China announced that the education of migrant children should be handled by the local governments at migrant destinations and completed mainly at full-time public primary and secondary schools (Liangweizhu in Chinese). In 2006, the adjusted Compulsory Education Laws of China established the Liangweizhu Pol$i c y$ as a basic law for the compulsory education of migrant children. This policy has been responsible for the increasing numbers of migrant children receiving education. In addition, the Chinese government has promised to remove the rural-urban differences, as well as the inequality experienced by migrant workers with rural Hukou. As a result, increasing numbers of children of migrant workers can now go to local public schools to continue their education at little expense. At he same time, increasing numbers of rural children, including previously left-behind children, are becoming migrant children. According to a survey in 2015, $80 \%$ of migrant children were studying in urban public schools (Yang 2017).

The migration benefits of migrant children can be explained by assimilation theory. According to the classical assimilation theory of sociology, upward social mobility can help to narrow social differences. The migration of parents could result in positive returns in terms of more education and opportunities for their offspring (Warner and Strole 1945). However, the segmented assimilation theory argues that migrants may face the social exclusion of local cultures and the labour market (Portes and Zhou 1993; Zhou 1997). Using data from the United States, Xie and Greenman (2011) provides evidence that migrant children perform better in education but also face at-risk behaviors. Considering the social context of migrants in China, this may also happen in urban areas. For example, using data from urban China, Xue (2018) finds that migrant children are exposed to hostile attitudes from natives. Specifically, segmented rural-urban household registration system (or Hukou system) in China can be a major barrier to migration and from being able to obtain its benefits. The typical characteristic of the Hukou system is the provision of urban public goods to a very narrowly designated local area. A migrant would be required to meet many conditions to enjoy the same entitlements as do the local residents. As a result, many children of the migrants who own the rural Hukou of nonlocal places cannot obtain an education easily in the cities, provoking the problem of left-behind children.

Recent studies have attempted to determine whether and how migration affects migrant children's development in China. However, the results are contradictory, given that they use different sources of data. On the one hand, some research argues that family migration could bring benefits to children's educational performance. Using data from the China Health and Nutrition Survey, Lu (2012) found that migrant children perform better than their rural counterparts in studies and health. Using data from the China Family Panel Studies (CFPS), Xu and Xie (2015) found that migration has significant and positive effects on children's 
development, including in the areas of mathematics and health. Chen and Feng (2019) argues that migrant children perform as well as local children, implying that the former obtain significant promotions compared to their rural counterparts. On the other hand, some studies report opposite findings. For example, using self-collected data, Wang et al. (2017) provided evidence that children in urban private schools perform worse than their rural counterparts in rural public schools. However, this study only considers migrant students in private schools that are provided for the children of casual laborers. As a result, the study might have underestimated the effects of children's migration on their performance.

Three difficulties were encountered in studying the effects of family migration on children's achievement at a national level. First, there is a shortage of nationally collected data. To date, most studies have only used the self-collected data of several specific provinces or cities. As a result, the findings are not nationally representative. Moreover, the selfcollected data samples may not be selected randomly; hence, the results may be biased. Second, the causal relationship between family migration and children's performance is hard to identify because of the limited availability of relevant data. Finally, the mechanism of how migration affects children's performance is unclear. This study uses a sample from a representative national psychological database to estimate how and why migration affects migrant children's academic performance. We pay specific attention to how family expectations and school quality affect children's development.

\section{Data}

\section{Data source}

This paper uses a sample from the unique dataset of the National Children's Study of China (NCSC), which was collected by Beijing Normal University. The NCSC was sponsored by the Ministry of Science and Technology and implemented by the State Key Laboratory of Cognitive Neurosciences and Learning at Beijing Normal University in 2009. In all, about 52 universities, institutes, and hospitals, along with 300 experts, participated in this project. More than 95,756 students from 600 schools in 100 counties in 25 provinces were surveyed. Hence, the data are nationally representative. The sample was collected using stratified three-stage random sampling with unequal probabilities. The dataset contains four parts: general cognitive ability, academic performance, social adjustment, and growth environment. Our study uses the academic performance dataset.
The NCSC has several advantages in studying the development of migrant children. First, the dataset is nationally representative and the sample size is considerably large. Second, the dataset is the most professional psychological dataset covering the whole of China to date. All items in the questionnaires are modified according to the children's ages of development and ethnicity. Finally, the dataset consists of detailed data regarding not only the cognitive skills of children but also the environmental data of their families and schools. As a result, not only can we control the family and school backgrounds, but we can also study how family environments respond to children's migration, i.e., we can study the mechanism of how family environment affects migrant children's cognitive abilities.

During data processing, we excluded children with urban Hukou for the following reasons. First, although the Hukou system has been more relaxed recently (and even canceled in most provinces), it still plays an important role in people's daily lives (Chan and Buckingham 2008). Second, local urban Hukou is still a prior condition to enjoying institutional resources and civil authority in China (Wang 2004; Wu and Treiman 2004), implying that children without local urban Hukou face difficulties in enjoying local public resources, such as education and health services. Being excluded from urban local resources is the most important problem faced by migrant children. In addition, the gap between citizens with and without prior Hukou is still very wide. As a result, it is necessary to limit our sample to people with rural Hukou.

\section{Outcome variables}

The major outcome variables include academic achievements in Chinese and mathematics. Academic performances are usually seen as cognitive abilities. Some research has argued that cognitive ability is not only one of the major determinants of decisions about education and income but is also a basis for decisions about returning to education and participation in training (Cunha et al. 2006; Heckman et al. 2006; Cunha and Heckman 2009). In addition, compared to education measured as years in school or level of education, the quality of education measured as academic performance and cognitive achievement is more important (Hanushek and Woessmann 2008).

The NCSC tested all students using the same examinations throughout the country, so the scores are comparable across schools and regions. Chinese examinations have 38 items testing linguistic knowledge, cultural knowledge, and reading. Mathematics examinations have 29 items testing arithmetic, algebra, geometry,statistics, probability, 

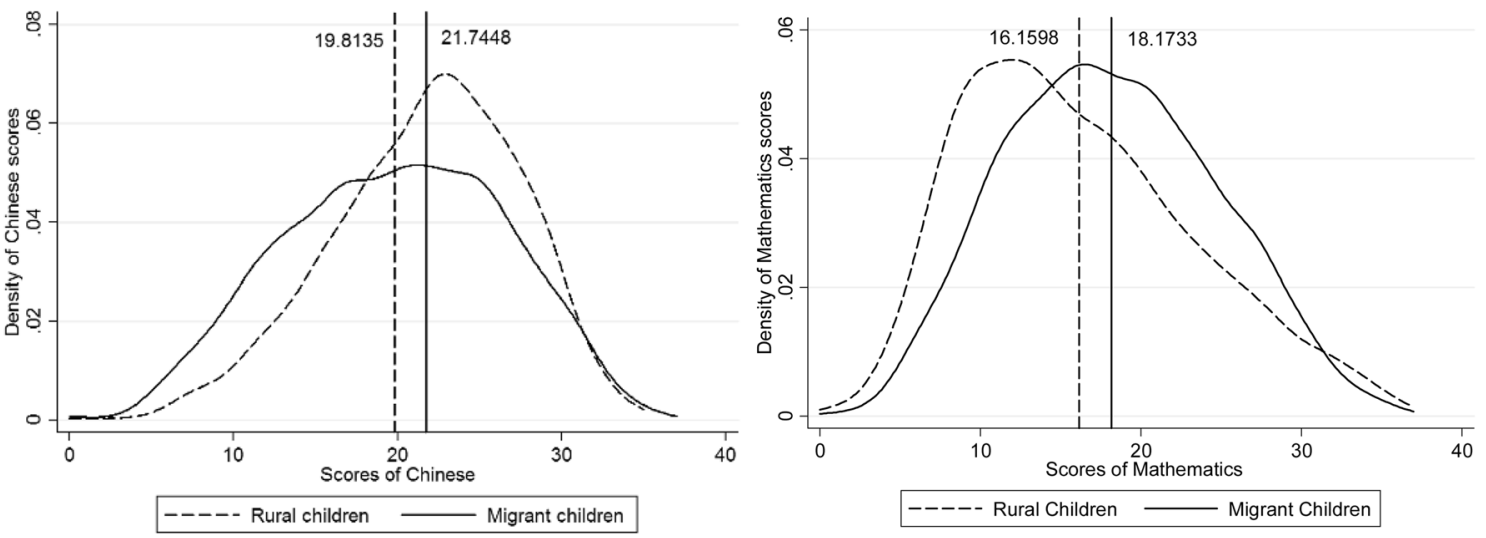

Fig. 1 Distribution of children's academic performance. Source: National Children's Study of China, 2009

knowledge of the facts, applications of the rules, and mathematical reasoning, and problem-solving. The fullest possible marks for each examination are 38 points. ${ }^{1} \mathrm{We}$ standardize the values and thus the means of both tests are equal to 0 .

\section{Treatment variable}

Treatment variable pertains to children who have migrated to urban areas and have parents whose major occupations are non-agricultural in 2009. Generally speaking, a migrant child will leave their hometown to live in a city. Note that some children leave their hometowns but live in another town far from their own. Because we are only concerned with rural-urban migration, observations of migrant children whose fathers' major occupation is farming have been excluded.

We have also restricted the sample of rural children to those whose fathers' major occupation is farming. This definition is close to our traditional identification of rural-urban migration. We obtained 6106 observations of 2198 migrant and 3818 rural children. The ratio of migrants to rural children is much higher than expected because increasing numbers of parents in villages are not working in agricultural jobs. As a result, pure farmers are becoming rarer. We can relax the definition of rural children to include non-agricultural workers in later estimations, but the major results are almost identical.

Figure 1 presents the distribution of the academic performances of children based on our sample but excluding samples with parents in non-agricultural jobs. The average differences in the children's educational outcomes are about

\footnotetext{
$\overline{1}$ The NCSC also provides predicted scores of mathematics and Chinese based on item response theory and classical test theory. However, we prefer the original test scores, because there may be bias when calculating the predicted values.
}

2 points. The bottom of the educational outcomes for rural children contains smaller values than for migrant children. The corresponding means are shown in Table 1 . We can see that, on average, migrant and rural children's scores in Chinese and mathematics are 21.52 and 16.90 points, respectively. At the same time, the migrant children significantly outperform their rural counterparts by approximately 1.93 points in Chinese, and 2.01 points in mathematics. Roughly speaking, the gaps are approximately $10 \%$.

\section{Control variables}

Control variables include personal characteristics, family characteristics, family investments, and school characteristics. Personal characteristics include age, gender, educational stage (whether junior or middle school), kindergarten experience, and possession of Han ethnicity. Gender is defined as whether the child is male or female. The educational stage is defined as whether the child is at Grade 7 or above. The value of kindergarten experience is equal to 1 if the child has ever been to a kindergarten; otherwise, the value is 0 .

Family characteristics include the number of a child's siblings, father's education, mother's education, and family income (if more than 10,000 RMB per annum). According to the "quantity-quality" hypothesis, children's educational achievements are negatively correlated to family size (Becker and Lewis 1973). As a result, it is necessary to control the number of siblings. Father's education is defined as whether or not the father has at least a high school education. The mother's education is defined similarly.

We used the parents' educational expectations and material support for educational utilities as proxies for family investments. The parents' educational expectations are defined as the expectation of the parents of their child's earning of a university degree or above. As an important element of parents' involvement, parental expectation is significantly associated with children's academic achievement (Fan and 
Table 1 Comparison of mean characteristics of migrant children and non-left-behind rural children

\begin{tabular}{|c|c|c|c|c|}
\hline & Whole sample & Migrant children & Normal rural children & t-statistic \\
\hline \multicolumn{5}{|l|}{ A: academic outcomes } \\
\hline Chinese & 0 & $\begin{array}{l}0.1901 \\
(0.8873)\end{array}$ & $\begin{array}{l}-0.1094 \\
(1.0440)\end{array}$ & $1.9313 * * *$ \\
\hline Mathematics & 0 & $\begin{array}{l}0.1812 \\
(0.9311)\end{array}$ & $\begin{array}{l}-0.1043 \\
(1.0234)\end{array}$ & $2.0136^{* * *}$ \\
\hline \multicolumn{5}{|l|}{ A: personal characteristics } \\
\hline Age & $\begin{array}{l}11.7018 \\
(2.5589)\end{array}$ & $\begin{array}{l}11.1319 \\
(2.4444)\end{array}$ & $\begin{array}{l}12.0299 \\
(2.5660)\end{array}$ & $\begin{array}{l}-0.8979 * * * \\
(0.0675)\end{array}$ \\
\hline Female & $\begin{array}{l}0.4425 \\
(0.4967)\end{array}$ & $\begin{array}{l}0.4136 \\
(0.4926)\end{array}$ & $\begin{array}{l}0.4591 \\
(0.4984)\end{array}$ & $\begin{array}{l}-0.0456^{* * *} \\
(0.0133)\end{array}$ \\
\hline Educational stage & $\begin{array}{l}0.3793 \\
(0.4853)\end{array}$ & $\begin{array}{l}0.2780 \\
(0.4481)\end{array}$ & $\begin{array}{l}0.4377 \\
(0.4962)\end{array}$ & $\begin{array}{l}-0.1596 * * * \\
(0.0128)\end{array}$ \\
\hline Kindergarten experience & $\begin{array}{l}0.3138 \\
(0.4641)\end{array}$ & $\begin{array}{l}0.4563 \\
(0.4982)\end{array}$ & $\begin{array}{l}0.2318 \\
(0.4220)\end{array}$ & $\begin{array}{l}0.2245^{* * *} \\
(0.0121)\end{array}$ \\
\hline Han ethnicity & $\begin{array}{l}0.8762 \\
(0.3294)\end{array}$ & $\begin{array}{l}0.9190 \\
(0.2729)\end{array}$ & $\begin{array}{l}0.8515 \\
(0.3556)\end{array}$ & $\begin{array}{l}0.0676^{* * *} \\
(0.0088)\end{array}$ \\
\hline \multicolumn{5}{|l|}{ B: family characteristics } \\
\hline Number of siblings & $\begin{array}{l}2.1127 \\
(0.8447)\end{array}$ & $\begin{array}{l}1.9495 \\
(0.7987)\end{array}$ & $\begin{array}{l}2.2067 \\
(0.8562)\end{array}$ & $\begin{array}{l}-0.2572 * * * \\
(0.0224)\end{array}$ \\
\hline Father's education & $\begin{array}{l}0.5151 \\
(0.4998)\end{array}$ & $\begin{array}{l}0.7425 \\
(0.4374)\end{array}$ & $\begin{array}{l}0.5851 \\
(0.4928)\end{array}$ & $\begin{array}{l}0.1574 * * * \\
(0.0127)\end{array}$ \\
\hline Mother's education & $\begin{array}{l}0.4009 \\
(0.4901)\end{array}$ & $\begin{array}{l}0.5714 \\
(0.4950)\end{array}$ & $\begin{array}{l}0.4141 \\
(0.4926)\end{array}$ & $\begin{array}{l}0.1573 * * * \\
(0.0132)\end{array}$ \\
\hline Family income level & $\begin{array}{l}0.3735 \\
(0.4838)\end{array}$ & $\begin{array}{l}0.5601 \\
(0.4965)\end{array}$ & $\begin{array}{l}0.2661 \\
(0.4420)\end{array}$ & $\begin{array}{l}0.2939 * * * \\
(0.0124)\end{array}$ \\
\hline Parental expectations & $\begin{array}{l}0.6531 \\
(0.4760)\end{array}$ & $\begin{array}{l}0.7106 \\
(0.4536)\end{array}$ & $\begin{array}{l}0.6200 \\
(0.4855)\end{array}$ & $\begin{array}{l}0.0907 * * * \\
(0.0127)\end{array}$ \\
\hline Family's material support & $\begin{array}{l}0.2364 \\
(0.4249)\end{array}$ & $\begin{array}{l}0.3740 \\
(0.4840)\end{array}$ & $\begin{array}{l}0.1572 \\
(0.3640)\end{array}$ & $\begin{array}{l}0.2168 * * * \\
(0.0110)\end{array}$ \\
\hline \multicolumn{5}{|l|}{ C: school characteristics } \\
\hline School expenditure per student & $\begin{array}{l}5.8548 \\
(0.9437)\end{array}$ & $\begin{array}{l}923.5204 \\
(2176.8120)\end{array}$ & $\begin{array}{l}452.2241 \\
(625.6032)\end{array}$ & $\begin{array}{l}471.2962 * * * \\
(37.6699)\end{array}$ \\
\hline Teacher quality & $\begin{array}{l}0.3831 \\
(0.3030)\end{array}$ & $\begin{array}{l}0.4763 \\
(0.3203)\end{array}$ & $\begin{array}{l}0.3353 \\
(0.2871)\end{array}$ & $\begin{array}{l}0.1410 * * * \\
(0.0080)\end{array}$ \\
\hline School environment & $\begin{array}{l}3.2109 \\
(0.4421)\end{array}$ & $\begin{array}{l}3.3256 \\
(0.3930)\end{array}$ & $\begin{array}{l}3.1449 \\
(0.4552)\end{array}$ & $\begin{array}{l}0.1807 * * * \\
(0.0116)\end{array}$ \\
\hline Student-teacher ratio & $\begin{array}{l}18.5036 \\
(6.2529)\end{array}$ & $\begin{array}{l}18.0319 \\
(6.0487)\end{array}$ & $\begin{array}{l}18.6383 \\
(5.9988)\end{array}$ & $\begin{array}{l}0.6064 * * * \\
(0.1217)\end{array}$ \\
\hline Parental involvement & $\begin{array}{l}0.4435 \\
(0.4968)\end{array}$ & $\begin{array}{l}0.5364 \\
(0.4988)\end{array}$ & $\begin{array}{l}0.3900 \\
(0.4878)\end{array}$ & $\begin{array}{l}0.1464 * * * \\
(0.0132)\end{array}$ \\
\hline Average level of parents' education & $\begin{array}{l}0.2116 \\
(0.4085)\end{array}$ & $\begin{array}{l}0.3603 \\
(0.4802)\end{array}$ & $\begin{array}{l}0.1260 \\
(0.3319)\end{array}$ & $\begin{array}{l}0.2343 * * * \\
(0.0105)\end{array}$ \\
\hline Obs & 6016 & 2198 & 3818 & 6016 \\
\hline
\end{tabular}

Standard errors are shown in parentheses

Significance codes: $* * * p<0.01, * * p<0.05$, and $* p<0.1$ 
Chen 2001). Family material support is defined by the number of study utilities that is higher than four (top 20\% student ranking). Educational utilities provided by the family comprise of a computer, study desk, electronic dictionary, study materials, and extracurricular reading materials.

School characteristics consist of annual expenditure per student, teacher quality (measured as the percentage of teachers with university degrees), the student-teacher ratio, school environment (measured as the scores of students' behavioral problems), average level of parents' involvement in school affairs, and average level of parents' education. The parents' education is defined as above. Some school characteristics, such as the first three listed above, are also measurements of school quality. It is found that school quality is important to students' educational outcomes (Heyneman and Loxley 1983). As a result, we will pay closer attention to those characteristics.

Regional characteristics include regional categories and types of school locations. The data divide the regions into four categories. ${ }^{2}$ In our estimations, the fourth type is set as the control group. School locations include cities, counties or towns, and rural villages. In our estimations, rural villages are set as the control group.

\section{Summary statistics}

Table 1 reports the comparison of the mean characteristics of migrant children and non-left-behind rural children. Other than the means, Table 1 also presents the results of the t-test between the two groups, showing that both are significantly different in all aspects. Generally speaking, in terms of characteristics that would bring gains to children's educational outcomes, migrant children have more advantages.

Panel A reports the personal characteristics. Compared to rural children, migrant children tend to be younger, male, attending primary school, of Han ethnicity, and have more opportunities to attend kindergarten.

Panel B presents the summary statistics of family characteristics. It is obvious that the parents' levels of education are significantly higher. About $74 \%$ and $57 \%$ of migrant fathers and mothers, respectively, have finished compulsory (junior middle) school, whereas only $59 \%$ and $41 \%$ of rural children's fathers and mothers, respectively, have done so. In terms of family investments, the differences are also big. About $71 \%$ of migrant parents expect their children to attend

\footnotetext{
2 The first type includes Beijing, Tianjin, and Shanghai. The second type includes Zhejiang, Jiangsu, Shandong, Liaoning, Guangdong, and Jilin. The third type includes Fujian, Inner Mongolia, Heilongjiang, Shanxi, Hunan, Hubei, Hebei, Henan, Hainan, Guangxi, Chongqing, and Xinjiang. The fourth type includes Ningxia, Jiangxi, Shaanxi, Anhui, Sichuan, Qinghai, Yunnan, Gansu, Guizhou, and Xizang.
}

university but only $62 \%$ of rural parents expect that. The percentage of migrant families providing more than three types of study facilities is about twice that of rural families.

Panel C reports the summary statistics of school characteristics. We can see that the quality of urban schools is much higher than that of the rural schools in all aspects, especially school expenditures per student and teacher quality. The average school expenditure per student is 923.52 RMB in urban schools, whereas that of rural schools is 452.22 RMB or less than one-half of the expenditure of urban schools. The percentage of urban school teachers with university degrees is about $47.63 \%$, whereas that of rural school teachers is only $33.53 \%$. The school environment of migrant children is somewhat worse (high score implies worse school environment).

\section{Methodology}

Two types of estimation methods will be employed in this paper. First, the propensity score matching (PSM for short and hereinafter) method will be used to study the causal effects of migration on children's academic performances. The main goal of PSM is to find two children who have the same characteristics and compare their differences. Second, we use the Oaxaca-Blinder decomposition method (hereafter referred to as the OB decomposition) to identify the contributions of different characteristics to the academic gaps of children. The main idea of OB decomposition is to decompose the differences in the academic performance of the two groups (i.e., migrant children and rural children in this article) into two parts, namely the observed part and the unobserved part. The observed part consists of the contribution of observed characteristics. The unobserved part, meanwhile, is the remaining contribution that cannot be explained by the observed characteristics.

\section{Propensity score matching method}

A traditional OLS estimation approach is usually adopted to test for significant gaps between the achievements of migrant and non-left-behind rural children:

$Y_{i}=\alpha+\theta m i g_{i}+X_{i}^{\prime} \beta+\varepsilon_{i}$

where mig is the status of a child's migration to cities/counties/towns with parents who mainly work in non-agricultural jobs; $\mathrm{X}$ is the control variable, which is predetermined and includes all the control variables.

One problem with Eq. (1) is that it does not consider the self-selection problem. The self-selection problem stems from the fact that those who receive more marginal benefits are more likely to migrate. This implies that the 
characteristics of migrant children are different from those of non-left-behind rural children. Hence, the estimation will be biased. To avoid the self-selection problem this paper employs the method of propensity score matching proposed by Rosenbaum and Rubin (1983). This method has been widely used in the study of migration effects. For example, $\mathrm{Xu}$ and Xie (2015) employed this method to study the causal effects of migration on children's outcomes.

We simply describe this method as follows. Let $\mathrm{Y}^{\mathrm{m}}$ and $\mathrm{Y}^{\mathrm{r}}$ be the outcome of a migrant child and rural child, respectively. Then, average treatment effects on the treated (ATT) can be computed as:

$\mathrm{ATT}=E\left(Y^{m} \mid D=1\right)-E\left(Y^{r} \mid D=1\right)$

where $\mathrm{D}=1$ if being a migrant child, and 0 otherwise. To infer ATT, we need to assume that the treatment group (migrant children) and control group (non-left-behind rural children) are not systematically different in terms of approach is useful for analyzing the differences between the two groups and has been widely used in the literature on discrimination. Some researchers have also applied this approach to other aspects, such as health differentials among different groups (Van de Poel and Speybroeck 2009). Zhao et al. (2017) also uses it to study how the cognitive abilities of urban children achieve better results than those of their rural counterparts in China.

The OB decomposition can be explained as follows. First, we estimate the following equations for the academic performances of migrant children $(\mathrm{m})$ and non-left-behind rural children (r) separately:

$Y_{i j}=X_{i j}^{\prime} \beta_{j}+\varepsilon_{i j}, j=m, r$

where $X_{i j}$, including all control variables, is the same as the final model in the previous OLS estimation. According to the usual assumption, $\mathrm{E}\left[\varepsilon_{i j} \mid X_{i j}\right]=0, j=m, r$. Thus, the mean difference between these two groups is:

$\mathrm{GAP}=\bar{Y}_{m}-\bar{Y}_{r}=\bar{X}_{m}^{\prime} \hat{\beta}_{m}-\bar{X}_{r}^{\prime} \hat{\beta}_{r}=\left(\bar{X}_{m}-\bar{X}_{r}\right)^{\prime} \hat{\beta}_{r}+\left[\bar{X}_{r}^{\prime}\left(\hat{\beta}_{m}-\hat{\beta}_{r}\right)+\left(\bar{X}_{m}-\bar{X}_{r}\right)^{\prime}\left(\hat{\beta}_{m}-\hat{\beta}_{r}\right)\right]$

unobserved characteristics (once the children are matched based on observed characteristics) (Rosenbaum and Rubin, 1983). This is the so-called conditional independence assumption. Then, we can estimate the ATT as:

$\mathrm{ATT}=E\left[Y^{m} \mid D=1, \operatorname{Pr}(D=1 \mid X)\right]-E\left[Y^{r} \mid D=0, \operatorname{Pr}(D=1 \mid X)\right]$

where $\operatorname{Pr}(D=1 \mid X)$ is the probability of being treated, which is conditional on X. Note that the efficiency of PSM depends on the selection of the common support, based on which the treatment group and control group are determined. There are several matching methods, including caliper matching, interval matching, kernel matching, and local linear matching (Smith and Todd 2005). This paper presents results from local linear matching, given that method's relative efficiency.
This decomposition is the so-called three-fold decomposition, where $\hat{\beta}_{m}$ and $\hat{\beta}_{r}$ are the estimated coefficients of migrant and non-left-behind rural children samples, respectively. Equation (5) uses the coefficients for the rural sample as the reference coefficients. We can also use those of the migrant sample for reference. The first part of the decomposition in Eqs. (5) is the explained part because of the observed characteristics. This implies that, if both kinds of children have the same coefficients, the differences in their performance come from their observed characteristics. As a result, this is usually called the "endowment effect". The second part, in the square brackets, is unexplained and is usually called the "coefficient effect". Because we are mainly interested in the contributions of family investments and school quality, Eq. (5) can also be written as follows.

$\mathrm{GAP}=\left(\bar{X}_{m p}-\bar{X}_{r p}\right)^{\prime} \hat{\beta}_{r p}+\left(\bar{X}_{m f}-\bar{X}_{r f}\right)^{\prime} \hat{\beta}_{r f}+\left(\bar{X}_{m s c h}-\bar{X}_{r s c h}\right)^{\prime} \hat{\beta}_{r s c h}+$ unexplained part

\section{Oaxaca-Blinder decomposition}

The OB decomposition approach was developed by Oaxaca (1973) and Blinder (1973) to identify the contributions of different factors to gender income differences. This where $p$ represents predetermined personal and family characteristics. The $f$ represents family investments and sch represents school quality. The unexplained part is the second part in brackets in Eq. (5). 
Table 2 Results of OLS estimations

\begin{tabular}{|c|c|c|c|c|c|c|}
\hline & \multicolumn{3}{|l|}{ Chinese } & \multicolumn{3}{|c|}{ Mathematics } \\
\hline & (1) & $(2)$ & (3) & (4) & $(5)$ & (6) \\
\hline Migrant children & $\begin{array}{l}0.206^{* * *} \\
(0.030)\end{array}$ & $\begin{array}{l}0.25 * * * \\
(0.030)\end{array}$ & $\begin{array}{l}0.174 * * * \\
(0.031)\end{array}$ & $\begin{array}{l}0.217 * * * \\
(0.032)\end{array}$ & $\begin{array}{l}0.189 * * * \\
(0.032)\end{array}$ & $\begin{array}{l}0.102 * * * \\
(0.032)\end{array}$ \\
\hline Age & & $\begin{array}{l}0.022 * * * \\
(0.008)\end{array}$ & $\begin{array}{l}0.02 * * * \\
(0.008)\end{array}$ & & $\begin{array}{l}0.121 * * * \\
(0.007)\end{array}$ & $\begin{array}{l}0.127 * * * \\
(0.007)\end{array}$ \\
\hline Female & & $\begin{array}{l}0.157 * * * \\
(0.024)\end{array}$ & $\begin{array}{l}0.154 * * * \\
(0.023)\end{array}$ & & $\begin{array}{l}-0.047^{*} \\
(0.025)\end{array}$ & $\begin{array}{l}-0.042 * \\
(0.024)\end{array}$ \\
\hline Educational stage & & $\begin{array}{l}0.440 * * * \\
(0.041)\end{array}$ & $\begin{array}{l}0.295 * * * \\
(0.048)\end{array}$ & & $\begin{array}{l}-0.339 * * * \\
(0.040)\end{array}$ & $\begin{array}{l}-0.406^{* * * *} \\
(0.048)\end{array}$ \\
\hline Kindergarten experience & & $\begin{array}{l}0.094 * * * \\
(0.027)\end{array}$ & $\begin{array}{l}0.05 * * \\
(0.027)\end{array}$ & & $\begin{array}{l}0.062 * * \\
(0.028)\end{array}$ & $\begin{array}{l}0.023 \\
(0.027)\end{array}$ \\
\hline Han ethnicity & & $\begin{array}{l}0.248 * * * \\
(0.037)\end{array}$ & $\begin{array}{l}0.213 * * * \\
(0.037)\end{array}$ & & $\begin{array}{l}0.281 * * * \\
(0.036)\end{array}$ & $\begin{array}{l}0.230 * * * \\
(0.036)\end{array}$ \\
\hline Number of siblings & & $\begin{array}{l}-0.107 * * * \\
(0.015)\end{array}$ & $\begin{array}{l}-0.063 * * * \\
(0.015)\end{array}$ & & $\begin{array}{l}-0.113 * * * \\
(0.015)\end{array}$ & $\begin{array}{l}-0.075^{* * * *} \\
(0.015)\end{array}$ \\
\hline Father's education & & $\begin{array}{l}0.198 * * * \\
(0.028)\end{array}$ & $\begin{array}{l}0.174 * * * \\
(0.027)\end{array}$ & & $\begin{array}{l}0.154 * * * \\
(0.028)\end{array}$ & $\begin{array}{l}0.127 * * * \\
(0.028)\end{array}$ \\
\hline Mother's education & & $\begin{array}{l}0.181 * * * \\
(0.027)\end{array}$ & $\begin{array}{l}0.139 * * * \\
(0.026)\end{array}$ & & $\begin{array}{l}0.164 * * * \\
(0.028)\end{array}$ & $\begin{array}{l}0.124 * * * \\
(0.027)\end{array}$ \\
\hline Family inc. level & & & $\begin{array}{l}0.050 * \\
(0.026)\end{array}$ & & & $\begin{array}{l}0.095 * * * \\
(0.027)\end{array}$ \\
\hline Parental expectations & & & $\begin{array}{l}0.353 * * * \\
(0.025)\end{array}$ & & & $\begin{array}{l}0.404 * * * \\
(0.025)\end{array}$ \\
\hline Family material support & & & $\begin{array}{l}0.119 * * * \\
(0.029)\end{array}$ & & & $\begin{array}{l}0.113 * * * \\
(0.031)\end{array}$ \\
\hline School expenditure per student & & & $\begin{array}{l}0.072 * * * \\
(0.013)\end{array}$ & & & $\begin{array}{l}0.093 * * * \\
(0.013)\end{array}$ \\
\hline Teacher quality & & & $\begin{array}{l}0.24 * * * \\
(0.054)\end{array}$ & & & $\begin{array}{l}0.121 * * \\
(0.058)\end{array}$ \\
\hline School environment & & & $\begin{array}{l}-0.010 * * * \\
(0.002)\end{array}$ & & & $\begin{array}{l}-0.004 * \\
(0.002)\end{array}$ \\
\hline Student-teacher ratio & & & $\begin{array}{l}0.126 * * * \\
(0.033)\end{array}$ & & & $\begin{array}{l}0.147 * * * \\
(0.034)\end{array}$ \\
\hline Parental involvement & & & $\begin{array}{l}0.040 \\
(0.025)\end{array}$ & & & $\begin{array}{l}0.068 * * * \\
(0.025)\end{array}$ \\
\hline Average level of parents' education & & & $\begin{array}{l}0.038 \\
(0.286)\end{array}$ & & & $\begin{array}{l}0.002 \\
(0.342)\end{array}$ \\
\hline Constant & $\begin{array}{l}0.167 * * * \\
(0.032)\end{array}$ & $\begin{array}{l}-0.526^{* * * *} \\
(0.101)\end{array}$ & $\begin{array}{l}-1.681 * * * \\
(0.179)\end{array}$ & $\begin{array}{l}0.115 * * * \\
(0.032)\end{array}$ & $\begin{array}{l}-1.340 * * * \\
(0.097)\end{array}$ & $\begin{array}{l}-2.832 * * * \\
(0.178)\end{array}$ \\
\hline Regional fixed effects & YES & YES & YES & YES & YES & YES \\
\hline School location fixed effects & YES & YES & YES & YES & YES & YES \\
\hline Observations & 6016 & 6016 & 6016 & 6016 & 6016 & 6016 \\
\hline R-squared & 0.045 & 0.156 & 0.206 & 0.041 & 0.113 & 0.173 \\
\hline
\end{tabular}

Robust standard errors clustered at school level are shown in parentheses

Significance codes: $* * * p<0.01, * * p<0.05$, and $* p<0.1$ 
Table 3 OLS results of different samples

\begin{tabular}{|c|c|c|c|c|c|c|}
\hline & Chinese & & & Mathematics & & \\
\hline & Rural & Migrant & Pooled & Rural & Migrant & Pooled \\
\hline Migrant children & & & $\begin{array}{l}-0.174 * * * \\
(0.031)\end{array}$ & & & $\begin{array}{l}-0.102 * * * \\
(0.032)\end{array}$ \\
\hline Age & $\begin{array}{l}0.044 * * * \\
(0.010)\end{array}$ & $\begin{array}{l}-0.003 \\
(0.012)\end{array}$ & $\begin{array}{l}0.026 * * * \\
(0.008)\end{array}$ & $\begin{array}{l}0.132 * * * \\
(0.009)\end{array}$ & $\begin{array}{l}0.120 * * * \\
(0.011)\end{array}$ & $\begin{array}{l}0.127 * * * \\
(0.007)\end{array}$ \\
\hline Female & $\begin{array}{l}0.189 * * * \\
(0.030)\end{array}$ & $\begin{array}{l}0.096 * * * \\
(0.037)\end{array}$ & $\begin{array}{l}0.154 * * * \\
(0.023)\end{array}$ & $\begin{array}{l}-0.017 \\
(0.031)\end{array}$ & $\begin{array}{l}-0.086^{* *} \\
(0.038)\end{array}$ & $\begin{array}{l}-0.042 * \\
(0.024)\end{array}$ \\
\hline Educational stage & $\begin{array}{l}0.258 * * * \\
(0.063)\end{array}$ & $\begin{array}{l}0.273 * * * \\
(0.074)\end{array}$ & $\begin{array}{l}0.295^{* * * *} \\
(0.048)\end{array}$ & $\begin{array}{l}-0.400 * * * \\
(0.062)\end{array}$ & $\begin{array}{l}-0.458^{* * * *} \\
(0.077)\end{array}$ & $\begin{array}{l}-0.40 * * * \\
(0.048)\end{array}$ \\
\hline Kindergarten experience & $\begin{array}{l}0.100 * * * \\
(0.037)\end{array}$ & $\begin{array}{l}-0.021 \\
(0.039)\end{array}$ & $\begin{array}{l}0.055 * * \\
(0.027)\end{array}$ & $\begin{array}{l}0.058 \\
(0.037)\end{array}$ & $\begin{array}{l}-0.034 \\
(0.040)\end{array}$ & $\begin{array}{l}0.023 \\
(0.027)\end{array}$ \\
\hline Han ethnicity & $\begin{array}{l}0.22 * * * \\
(0.045)\end{array}$ & $\begin{array}{l}0.18 * * * \\
(0.068)\end{array}$ & $\begin{array}{l}0.213 * * * \\
(0.037)\end{array}$ & $\begin{array}{l}0.279 * * * \\
(0.044)\end{array}$ & $\begin{array}{l}0.064 \\
(0.064)\end{array}$ & $\begin{array}{l}0.23 * * * \\
(0.036)\end{array}$ \\
\hline Number of siblings & $\begin{array}{l}-0.081^{* * *} \\
(0.020)\end{array}$ & $\begin{array}{l}-0.029 \\
(0.024)\end{array}$ & $\begin{array}{l}-0.063 * * * \\
(0.015)\end{array}$ & $\begin{array}{l}-0.104 * * * \\
(0.020)\end{array}$ & $\begin{array}{l}-0.012 \\
(0.024)\end{array}$ & $\begin{array}{l}-0.075^{* * *} \\
(0.015)\end{array}$ \\
\hline Father's education & $\begin{array}{l}0.224 * * * \\
(0.033)\end{array}$ & $\begin{array}{l}0.065 \\
(0.046)\end{array}$ & $\begin{array}{l}0.174 * * * \\
(0.027)\end{array}$ & $\begin{array}{l}0.129 * * * \\
(0.034)\end{array}$ & $\begin{array}{l}0.119 * * \\
(0.047)\end{array}$ & $\begin{array}{l}0.127 * * * \\
(0.028)\end{array}$ \\
\hline Mother's education & $\begin{array}{l}0.128 * * * \\
(0.034)\end{array}$ & $\begin{array}{l}0.145 * * * \\
(0.041)\end{array}$ & $\begin{array}{l}0.139 * * * \\
(0.026)\end{array}$ & $\begin{array}{l}0.112 * * * \\
(0.035)\end{array}$ & $\begin{array}{l}0.140 * * * \\
(0.042)\end{array}$ & $\begin{array}{l}0.124 * * * \\
(0.027)\end{array}$ \\
\hline Family inc. level & $\begin{array}{l}0.037 \\
(0.036)\end{array}$ & $\begin{array}{l}0.035 \\
(0.037)\end{array}$ & $\begin{array}{l}0.050 * \\
(0.026)\end{array}$ & $\begin{array}{l}0.081 * * \\
(0.038)\end{array}$ & $\begin{array}{l}0.078 * * \\
(0.038)\end{array}$ & $\begin{array}{l}0.095 * * * \\
(0.027)\end{array}$ \\
\hline Parental expectations & $\begin{array}{l}0.366^{* * * *} \\
(0.031)\end{array}$ & $\begin{array}{l}0.321 * * * \\
(0.042)\end{array}$ & $\begin{array}{l}0.353 * * * \\
(0.025)\end{array}$ & $\begin{array}{l}0.421 * * * \\
(0.032)\end{array}$ & $\begin{array}{l}0.362 * * * \\
(0.042)\end{array}$ & $\begin{array}{l}0.404 * * * \\
(0.025)\end{array}$ \\
\hline Family material support & $\begin{array}{l}0.147 * * * \\
(0.042)\end{array}$ & $\begin{array}{l}0.125 * * * \\
(0.041)\end{array}$ & $\begin{array}{l}0.119 * * * \\
(0.029)\end{array}$ & $\begin{array}{l}0.105^{* *} \\
(0.046)\end{array}$ & $\begin{array}{l}0.136 * * * \\
(0.042)\end{array}$ & $\begin{array}{l}0.113 * * * \\
(0.031)\end{array}$ \\
\hline School expenditure per student & $\begin{array}{l}0.119 * * * \\
(0.019)\end{array}$ & $\begin{array}{l}0.005 \\
(0.019)\end{array}$ & $\begin{array}{l}0.072 * * * \\
(0.013)\end{array}$ & $\begin{array}{l}0.132 * * * \\
(0.019)\end{array}$ & $\begin{array}{l}0.041 * * \\
(0.019)\end{array}$ & $\begin{array}{l}0.093 * * * \\
(0.013)\end{array}$ \\
\hline Teacher quality & $\begin{array}{l}0.328 * * * \\
(0.076)\end{array}$ & $\begin{array}{l}0.15 * * \\
(0.078)\end{array}$ & $\begin{array}{l}0.248 * * * \\
(0.054)\end{array}$ & $\begin{array}{l}0.163 * * \\
(0.082)\end{array}$ & $\begin{array}{l}0.069 \\
(0.081)\end{array}$ & $\begin{array}{l}0.121 * * \\
(0.058)\end{array}$ \\
\hline School environment & $\begin{array}{l}-0.012^{* * *} \\
(0.003)\end{array}$ & $\begin{array}{l}-0.005 \\
(0.003)\end{array}$ & $\begin{array}{l}-0.010^{* * *} \\
(0.002)\end{array}$ & $\begin{array}{l}-0.005^{*} \\
(0.003)\end{array}$ & $\begin{array}{l}0.001 \\
(0.003)\end{array}$ & $\begin{array}{l}-0.004^{*} \\
(0.002)\end{array}$ \\
\hline Student-teacher ratio & $\begin{array}{l}0.099 * * \\
(0.041)\end{array}$ & $\begin{array}{l}0.156^{* * * *} \\
(0.057)\end{array}$ & $\begin{array}{l}0.126 * * * \\
(0.033)\end{array}$ & $\begin{array}{l}0.116^{* * * *} \\
(0.041)\end{array}$ & $\begin{array}{l}0.199 * * * \\
(0.058)\end{array}$ & $\begin{array}{l}0.147 * * * \\
(0.034)\end{array}$ \\
\hline Parental involvement & $\begin{array}{l}0.035 \\
(0.032)\end{array}$ & $\begin{array}{l}0.06^{*} \\
(0.039)\end{array}$ & $\begin{array}{l}0.040 \\
(0.025)\end{array}$ & $\begin{array}{l}0.046 \\
(0.033)\end{array}$ & $\begin{array}{l}0.107 * * * \\
(0.040)\end{array}$ & $\begin{array}{l}0.068^{* * * *} \\
(0.025)\end{array}$ \\
\hline Average level of parents' education & $\begin{array}{l}0.014 \\
(0.049)\end{array}$ & $\begin{array}{l}0.028 \\
(0.040)\end{array}$ & $\begin{array}{l}0.038 \\
(0.031)\end{array}$ & $\begin{array}{l}0.011 \\
(0.046)\end{array}$ & $\begin{array}{l}-0.025 \\
(0.043)\end{array}$ & $\begin{array}{l}0.002 \\
(0.031)\end{array}$ \\
\hline Constant & $\begin{array}{l}-2.066^{* * *} \\
(0.246)\end{array}$ & $\begin{array}{l}-1.042 * * * \\
(0.283)\end{array}$ & $\begin{array}{l}-1.681 * * * \\
(0.179)\end{array}$ & $\begin{array}{l}-3.032 * * * \\
(0.250)\end{array}$ & $\begin{array}{l}-2.607^{* * * *} \\
(0.279)\end{array}$ & $\begin{array}{l}-2.832 * * * \\
(0.178)\end{array}$ \\
\hline Regional fixed effects & YES & YES & YES & YES & YES & YES \\
\hline School location fixed effects & YES & YES & YES & YES & YES & YES \\
\hline Observations & 3.818 & 2.198 & 6.016 & 3.818 & 2.198 & 6.016 \\
\hline R-squared & 0.238 & 0.110 & 0.199 & 0.180 & 0.130 & 0.168 \\
\hline
\end{tabular}

Robust standard errors clustered at school level are shown in parentheses. Other variables are the same as those in previous tables Significance codes: $* * * p<0.01, * * p<0.05$, and $* p<0.1$ 
Table 4 Results of propensity score matching method

\begin{tabular}{lcc}
\hline Models & Chinese & Mathematics \\
\hline Model 1 & $0.1381^{* *}$ & $0.1901^{* * *}$ \\
& $(0.0642)$ & $(0.0475)$ \\
Model 2 & 0.0895 & $0.1152^{* *}$ \\
& $(0.0566)$ & $(0.0507)$ \\
Model 3 & 0.0544 & $0.0928^{*}$ \\
& $(0.0520)$ & $(0.0522)$ \\
\hline
\end{tabular}

Values in parentheses are bootstrap standard errors with 200 iterations. The matching method is local linear regression matching, and the bandwidth is 0.001

Significance codes: $* * * p<0.01, * * p<0.05$, and $* p<0.1$

\section{Empirical results}

\section{Baseline estimation: OLS estimation}

Table 3 illustrates the results of the OLS estimation when we add more control variables into the regression equation. Columns (1-3) and (4-6) present the estimates of the scores in Chinese and mathematics, respectively. Columns (1) and (3) contain only regional characteristics. Step by step, we added personal predetermined, family, and school characteristics. Table 2 shows that the migration status is significantly and positively associated with the children's scores in Chinese and mathematics. Before the controlling of the personal, family, and school characteristics, the gaps were 1.331 points for Chinese, and 1.531 points for mathematics. After adding all control variables, the gaps decreased to 1.172 points for Chinese, and 0.755 points for mathematics. The gaps are approximately $6.07 \%$ of the average scores in Chinese, and $3.76 \%$ of the average scores in mathematics, respectively.

Table 3 compares a set of OLS estimations using different samples. We repeated the same estimations as those in Columns (3) and (6) in Table 2. The left panel shows the results for the scores in Chinese, while the right panel shows those for mathematics. In each panel, we report the results based on the non-left-behind rural children sample, migrant children sample, and full samples in the first, second, and third columns, respectively. Table 3 not only enables us to examine the contributions of different characteristics but also plays a role in the first stage of the OB decomposition analysis, as explained in the next section.

From Table 3, we can obtain three interesting findings regarding the heterogeneities of migrant and non-left-behind rural children. The first finding is that migrant children cannot benefit more from kindergarten experiences. In other words, kindergarten experiences do not significantly affect migrant children. There are two potential explanations for this. First, changes in the environment do not allow for stable lives in kindergarten. Second, the parents of migrant children cannot afford the expense of high-quality kindergartens.

The second is that the number of siblings has no significant effects on migrant children. An intuitive explanation is the smaller number of siblings of migrant children. Another explanation is the ability of migrant families to afford to invest more in their children, thereby mitigating the negative effects of family size.

The third finding is the significant benefits received by non-left-behind rural children, but not migrant children, from the school investment. Three possible explanations can be offered for this surprising result. First, the migrant children encounter adjustment problems in their daily lives and so cannot benefit from increases in school investments. Second, urban schools receive more than sufficient investment. Finally, migrant children are exposed to social exclusions in schools.

\section{Results: propensity score matching method}

The major problem with the above OLS estimation is that it does not consider the selection problems. To identify the causal relationship between family migration and children's achievements, this paper employs the propensity score matching method. The PSM results are presented in Table 4. We can employ different matching methods to calculate the ATT. We prefer the results of local linear regression matching because of its relative efficiency. As a result, we will take the results of local linear regression matching as our main results (more information about the results of PSM are shown in Tables 7-9 in Appendix). In Table 4, three models are considered. The first model only contains predetermined personal and family characteristics and the regional fixed effects. Then, we add school characters to model 2. Finally, we add family investments and family income level to the model because these variables are not predetermined to children's outcomes. This way can help us to see the role of school and family investments roughly.

From model 1 in Table 4, we can see that migrant children perform significantly better in Chinese and mathematics. Specifically, migrant children outperform their rural counterparts in terms of their scores in Chinese and mathematics by 0.13 and 0.19 standard deviations, respectively. When we continued to control the level of school quality, the difference in children's scores in Chinese turned to insignificant. Meanwhile, the differences in mathematics were still 
Table 5 Oaxaca-Blinder decomposition results

\begin{tabular}{|c|c|c|c|c|c|c|}
\hline \multirow[t]{2}{*}{ Reference coefficients } & \multicolumn{3}{|l|}{ Chinese } & \multicolumn{3}{|l|}{ Mathematics } \\
\hline & $\begin{array}{l}\text { Mig coef } \\
\text { (1) }\end{array}$ & $\begin{array}{l}\text { Rural coef } \\
\text { (2) }\end{array}$ & $\begin{array}{l}\text { Pooled coef } \\
\text { (3) }\end{array}$ & $\begin{array}{l}\text { Mig coef } \\
\text { (4) }\end{array}$ & $\begin{array}{l}\text { Rural coef } \\
(5)\end{array}$ & $\begin{array}{l}\text { Pooled coef } \\
\text { (6) }\end{array}$ \\
\hline $\operatorname{Gap}\left(\overline{\mathrm{Y}}_{\text {mig }}-\bar{Y}_{\text {rural }}\right)$ & $\begin{array}{l}0.285^{* * *} * \\
(0.026)\end{array}$ & $\begin{array}{l}0.285 * * * \\
(0.026)\end{array}$ & $\begin{array}{l}0.285^{* * *} \\
(0.026)\end{array}$ & $\begin{array}{l}0.300 * * * \\
(0.025)\end{array}$ & $\begin{array}{l}0.300 * * * \\
(0.025)\end{array}$ & $\begin{array}{l}0.300 * * * \\
(0.025)\end{array}$ \\
\hline Endowments & $\begin{array}{l}0.226 * * * \\
(0.042)\end{array}$ & $\begin{array}{l}0.177 * * * \\
(0.029)\end{array}$ & $\begin{array}{l}0.184 * * * \\
(0.023)\end{array}$ & $\begin{array}{l}0.224 * * * \\
(0.042)\end{array}$ & $\begin{array}{l}0.118^{* * * *} \\
(0.028)\end{array}$ & $\begin{array}{l}0.126 * * * \\
(0.023)\end{array}$ \\
\hline Age & $\begin{array}{l}-0.118^{* * *} \\
(0.012)\end{array}$ & $\begin{array}{l}-0.108 * * * \\
(0.013)\end{array}$ & $\begin{array}{l}-0.11^{* * *} \\
(0.011)\end{array}$ & $\begin{array}{l}-0.040 * * * \\
(0.009)\end{array}$ & $\begin{array}{l}0.003 \\
(0.010)\end{array}$ & $\begin{array}{l}-0.023^{* * *} \\
(0.007)\end{array}$ \\
\hline Female & $\begin{array}{l}0.001 \\
(0.001)\end{array}$ & $\begin{array}{l}0.004 * \\
(0.002)\end{array}$ & $\begin{array}{l}0.002 \\
(0.001)\end{array}$ & $\begin{array}{l}-0.009 * * * \\
(0.003)\end{array}$ & $\begin{array}{l}-0.004^{* *} \\
(0.002)\end{array}$ & $\begin{array}{l}-0.007^{* * * *} \\
(0.002)\end{array}$ \\
\hline Educational stage & $\begin{array}{l}0.06^{* * *} \\
(0.011)\end{array}$ & $\begin{array}{l}0.073 * * * \\
(0.014)\end{array}$ & $\begin{array}{l}0.06 * * * \\
(0.009)\end{array}$ & $\begin{array}{l}-0.041 * * * \\
(0.010)\end{array}$ & $\begin{array}{l}-0.044 * * * \\
(0.012)\end{array}$ & $\begin{array}{l}-0.047 * * * \\
(0.009)\end{array}$ \\
\hline Kindergarten experience & $\begin{array}{l}0.013 \\
(0.009)\end{array}$ & $\begin{array}{l}-0.008 \\
(0.009)\end{array}$ & $\begin{array}{l}0.005 \\
(0.006)\end{array}$ & $\begin{array}{l}0.022 * * * \\
(0.008)\end{array}$ & $\begin{array}{l}-0.005 \\
(0.009)\end{array}$ & $\begin{array}{l}0.012 * * \\
(0.006)\end{array}$ \\
\hline Han ethnicity & $\begin{array}{l}0.019 * * * \\
(0.004)\end{array}$ & $\begin{array}{l}0.004 \\
(0.005)\end{array}$ & $\begin{array}{l}0.016^{* * * *} \\
(0.003)\end{array}$ & $\begin{array}{l}0.015 * * * \\
(0.004)\end{array}$ & $\begin{array}{l}0.012 * * * \\
(0.005)\end{array}$ & $\begin{array}{l}0.014 * * * \\
(0.003)\end{array}$ \\
\hline Number of siblings & $\begin{array}{l}0.027 * * * \\
(0.006)\end{array}$ & $\begin{array}{l}0.003 \\
(0.006)\end{array}$ & $\begin{array}{l}0.019 * * * \\
(0.004)\end{array}$ & $\begin{array}{l}0.021 * * * \\
(0.005)\end{array}$ & $\begin{array}{l}0.007 \\
(0.006)\end{array}$ & $\begin{array}{l}0.016 * * * \\
(0.004)\end{array}$ \\
\hline Father's education & $\begin{array}{l}0.020 * * * \\
(0.006)\end{array}$ & $\begin{array}{l}0.019 * * \\
(0.008)\end{array}$ & $\begin{array}{l}0.020 * * * \\
(0.005)\end{array}$ & $\begin{array}{l}0.035 * * * \\
(0.006)\end{array}$ & $\begin{array}{l}0.010 \\
(0.007)\end{array}$ & $\begin{array}{l}0.027 * * * \\
(0.005)\end{array}$ \\
\hline Mother's education & $\begin{array}{l}0.01 * * * \\
(0.006)\end{array}$ & $\begin{array}{l}0.022 * * * \\
(0.007)\end{array}$ & $\begin{array}{l}0.020 * * * \\
(0.005)\end{array}$ & $\begin{array}{l}0.020 * * * \\
(0.006)\end{array}$ & $\begin{array}{l}0.023 * * * \\
(0.007)\end{array}$ & $\begin{array}{l}0.022 * * * \\
(0.005)\end{array}$ \\
\hline Family income level & $\begin{array}{l}0.024 * * \\
(0.011)\end{array}$ & $\begin{array}{l}0.023 * * \\
(0.011)\end{array}$ & $\begin{array}{l}0.028 * * * \\
(0.008)\end{array}$ & $\begin{array}{l}0.011 \\
(0.010)\end{array}$ & $\begin{array}{l}0.010 \\
(0.011)\end{array}$ & $\begin{array}{l}0.01 * \\
(0.008)\end{array}$ \\
\hline Parental expectations & $\begin{array}{l}0.038 * * * \\
(0.006)\end{array}$ & $\begin{array}{l}0.033 * * * \\
(0.006)\end{array}$ & $\begin{array}{l}0.03 * * * \\
(0.006)\end{array}$ & $\begin{array}{l}0.033 * * * \\
(0.005)\end{array}$ & $\begin{array}{l}0.029 * * * \\
(0.005)\end{array}$ & $\begin{array}{l}0.032 * * * \\
(0.005)\end{array}$ \\
\hline Family material support & $\begin{array}{l}0.023 * * \\
(0.010)\end{array}$ & $\begin{array}{l}0.029 * * * \\
(0.009)\end{array}$ & $\begin{array}{l}0.025 * * * \\
(0.007)\end{array}$ & $\begin{array}{l}0.032 * * * \\
(0.009)\end{array}$ & $\begin{array}{l}0.027 * * * \\
(0.009)\end{array}$ & $\begin{array}{l}0.026 * * * \\
(0.006)\end{array}$ \\
\hline School expenditure per student & $\begin{array}{l}0.037 * * * \\
(0.007)\end{array}$ & $\begin{array}{l}0.012 * * \\
(0.006)\end{array}$ & $\begin{array}{l}0.026^{* * *} \\
(0.005)\end{array}$ & $\begin{array}{l}0.034 * * * \\
(0.006)\end{array}$ & $\begin{array}{l}0.002 \\
(0.005)\end{array}$ & $\begin{array}{l}0.02 * * * \\
(0.004)\end{array}$ \\
\hline Teacher quality & $\begin{array}{l}0.022 * * \\
(0.011)\end{array}$ & $\begin{array}{l}0.009 \\
(0.011)\end{array}$ & $\begin{array}{l}0.016^{* *} \\
(0.008)\end{array}$ & $\begin{array}{l}0.044 * * * \\
(0.011)\end{array}$ & $\begin{array}{l}0.021 * \\
(0.011)\end{array}$ & $\begin{array}{l}0.033 * * * \\
(0.008)\end{array}$ \\
\hline School environment & $\begin{array}{l}0.003 \\
(0.002)\end{array}$ & $\begin{array}{l}-0.001 \\
(0.002)\end{array}$ & $\begin{array}{l}0.002 * \\
(0.002)\end{array}$ & $\begin{array}{l}0.008 * * * \\
(0.003)\end{array}$ & $\begin{array}{l}0.003 \\
(0.002)\end{array}$ & $\begin{array}{l}0.007 * * * \\
(0.002)\end{array}$ \\
\hline Student-teacher ratio & $\begin{array}{l}0.021 * * * \\
(0.007)\end{array}$ & $\begin{array}{l}0.036 * * * \\
(0.011)\end{array}$ & $\begin{array}{l}0.027 * * * \\
(0.006)\end{array}$ & $\begin{array}{l}0.018 * * \\
(0.007)\end{array}$ & $\begin{array}{l}0.028 * * * \\
(0.010)\end{array}$ & $\begin{array}{l}0.023 * * * \\
(0.006)\end{array}$ \\
\hline Parental involvement & $\begin{array}{l}0.007 \\
(0.005)\end{array}$ & $\begin{array}{l}0.01 * * * \\
(0.006)\end{array}$ & $\begin{array}{l}0.01 * * * \\
(0.004)\end{array}$ & $\begin{array}{l}0.005 \\
(0.005)\end{array}$ & $\begin{array}{l}0.009 \\
(0.006)\end{array}$ & $\begin{array}{l}0.006 \\
(0.004)\end{array}$ \\
\hline Average level of parents' education & $\begin{array}{l}-0.003 \\
(0.013)\end{array}$ & $\begin{array}{l}0.007 \\
(0.011)\end{array}$ & $\begin{array}{l}-0.001 \\
(0.008)\end{array}$ & $\begin{array}{l}-0.004 \\
(0.013)\end{array}$ & $\begin{array}{l}-0.007 \\
(0.011)\end{array}$ & $\begin{array}{l}-0.010 \\
(0.008)\end{array}$ \\
\hline Unexplained part & $\begin{array}{l}0.059 \\
(0.047)\end{array}$ & $\begin{array}{l}0.109 * * * \\
(0.037)\end{array}$ & $\begin{array}{l}0.102 * * * \\
(0.032)\end{array}$ & $\begin{array}{l}0.076 \\
(0.047)\end{array}$ & $\begin{array}{l}0.182 * * * \\
(0.035)\end{array}$ & $\begin{array}{l}0.174 * * * \\
(0.031)\end{array}$ \\
\hline Observations & 6016 & 6016 & 6016 & 6016 & 6016 & 6016 \\
\hline
\end{tabular}

Standard errors are shown in parentheses

Significance codes: $* * * p<0.01, * * p<0.05$, and $* p<0.1$ 
significant. After we added family investment to the estimation models, the differences in mathematics scores became weakly significant and were not robust. The differences in Chinese scores were still insignificant. These results suggest that school quality and family investment can explain a large part of the differences in academic performances, to some extent. This paper then continued to apply the OaxacaBlinder decomposition method to obtain the exact contribution of family investment and school quality.

\section{Results: Oaxaca-Blinder decomposition}

\section{Overall decomposition}

Table 5 reports the results of the Oaxaca-Blinder decomposition. In Table 5, we can see that the differences between the scores in Chinese and mathematics of the migrant and non-left-behind rural children are 1.931 and 2.014 points, respectively. The gaps are nearly $10 \%$ and $12 \%$, respectively, of the average score of all students. The contributions of the explained and the unexplained parts depend on the reference coefficients. Among the indicators of the explained part, the family's socioeconomic status and school quality play the most important roles. Specifically, the variables of the educational stage (whether the student is of junior middle school), whether the mother's education is a high school or above, whether parents expect children to get a university education degree or above, family material support, and school environment are all consistently significant. Our findings are consistent with those of Potochnick (2014), i.e. that the characteristics of families and schools strongly influence the achievements of immigrants.

Column (1)-(3) show the results of the decomposition of Chinese using coefficients of the migrant group, rural group and pooled model over both groups as the reference coefficients, respectively. Because the pooled model includes the migration indicator as a control variable and contains information of both groups, we prefer the results of column (3) and we use it as this study's baseline result for discussion. We can see that the explained part amounts to 0.184 standard deviations accounting for $64.56 \%$ of the total difference. Family investments and school quality are essential contributors to the gains of migration, especially parental expectation. The contributions of family investment and school quality are $21.75 \%$ and $28.42 \%$, respectively. It seems that school quality is a bit more important. At the same time, the most important factors include parental expectations, family material support, school expenditure per student, teacher quality, and student-teacher ratio. These factors account for approximately $12.98 \%, 8.77 \%, 9.12 \%, 5.61 \%$, and $9.47 \%$ of the gap, respectively. The school environment is not an essential but significant factor.
Columns (4-6) report the results of the migration gains of children in terms of their scores in mathematics. The gap is 0.30 standard deviations. We can see that the detailed decomposition patterns are similar and close to that of the decomposition of the gap for Chinese. The family investments and school quality are still the most important contributors to the gap and they amount to $19.33 \%$ and $29.67 \%$, respectively. As discussed above, we prefer the results using pooled coefficients as reference coefficients in column (6). Compared to the decomposition of the gap of Chinese, there are several changes in the decomposition of the gap for mathematics. Gender is an important factor now. The educational stage changes its sign to become a positive contributor. Family income level becomes a weakly positive contributor. Family investments and school quality are still the most important contributors. Parental expectations, family material support, school expenditure, teacher quality, and student-teacher are still among the most important factors of the total differences and constitute about $10.67 \%, 8.67 \%$, $6.67 \%, 11.00 \%$, and $7.67 \%$, respectively, of the differences. Compared to the decomposition of the differences in the Chinese scores, the contributions of family investments and school quality are quite similar.

To sum up, the OB decomposition results show that approximately $50 \%$ of the differences in scores in Chinese and mathematics can be explained by observed characteristics. The most important elements include parental expectations about their children's final education, family material support, school investment, teacher quality, and student-teacher ratio are the most significant and powerful explanations for the differences. These five characteristics amount to nearly half of the total differences. Regional types sometimes also play roles in determining children's performance. Because of the heterogeneous character of regions, we did not pay much attention to the contributions of the regions.

\section{Contributions of coefficient differences}

Note that the unexplained part also contributes to a great part of the differences. According to Eq. (5), the unexplained part consists of two components: coefficients and interactions. The differences in the coefficients are important because they reflect the different effects of the observed characteristics. In the literature on discrimination, the different effects are also defined as discrimination and suggest different returns of the observed characteristics, especially education and experience. In our case, studying the differences in the coefficients could help us to understand the relative importance of the different observed characteristics. We were particularly concerned with the relative importance of family education investments and school quality. 
Table 6 OB decomposition of coefficients (three-fold decomposition)

\begin{tabular}{|c|c|c|c|c|}
\hline \multirow[t]{2}{*}{ Reference coefficients } & \multicolumn{2}{|l|}{ Chinese } & \multicolumn{2}{|l|}{ Mathematics } \\
\hline & $\begin{array}{l}\text { Mig. Coef } \\
\text { (3) }\end{array}$ & $\begin{array}{l}\text { Rural Coef } \\
\text { (4) }\end{array}$ & $\begin{array}{l}\text { Mig. Coef } \\
\text { (1) }\end{array}$ & $\begin{array}{l}\text { Rural Coef } \\
\text { (2) }\end{array}$ \\
\hline $\operatorname{Gap}\left(\overline{\mathrm{Y}}_{\text {mig }}-\bar{Y}_{\text {rural }}\right)$ & $\begin{array}{l}0.2854 * * * \\
(0.0260)\end{array}$ & $\begin{array}{l}0.2854 * * * \\
(0.0260)\end{array}$ & $\begin{array}{l}0.2995 * * * \\
(0.0255)\end{array}$ & $\begin{array}{l}0.2995 * * * \\
(0.0255)\end{array}$ \\
\hline Endowments & $\begin{array}{l}0.2260 * * * \\
(0.0423)\end{array}$ & $\begin{array}{l}0.1766^{* * *} \\
(0.0290)\end{array}$ & $\begin{array}{l}0.2237 * * * \\
(0.0421)\end{array}$ & $\begin{array}{l}0.1176^{* * * *} \\
(0.0278)\end{array}$ \\
\hline Coefficients & $\begin{array}{l}0.1088 * * * \\
(0.0366)\end{array}$ & $\begin{array}{l}0.0594 \\
(0.0474)\end{array}$ & $\begin{array}{l}0.1819 * * * \\
(0.0355)\end{array}$ & $\begin{array}{l}0.0758 \\
(0.0466)\end{array}$ \\
\hline Interaction & $\begin{array}{l}-0.0494 \\
(0.0494)\end{array}$ & $\begin{array}{l}0.0494 \\
(0.0494)\end{array}$ & $\begin{array}{l}-0.1061^{* *} \\
(0.0485)\end{array}$ & $\begin{array}{l}0.1061 * * \\
(0.0485)\end{array}$ \\
\hline Age & $\begin{array}{l}-0.1415 \\
(0.1851)\end{array}$ & $\begin{array}{l}-0.1310 \\
(0.1713)\end{array}$ & $\begin{array}{l}-0.5722 * * * \\
(0.1797)\end{array}$ & $\begin{array}{l}-0.5295^{* * *} \\
(0.1663)\end{array}$ \\
\hline Female & $\begin{array}{l}-0.0317 \\
(0.0226)\end{array}$ & $\begin{array}{l}-0.0285 \\
(0.0203)\end{array}$ & $\begin{array}{l}-0.0425^{*} \\
(0.0219)\end{array}$ & $\begin{array}{l}-0.0383^{*} \\
(0.0198)\end{array}$ \\
\hline Educational stage & $\begin{array}{l}-0.0255 \\
(0.0436)\end{array}$ & $\begin{array}{l}-0.0162 \\
(0.0277)\end{array}$ & $\begin{array}{l}0.0064 \\
(0.0423)\end{array}$ & $\begin{array}{l}0.0041 \\
(0.0269)\end{array}$ \\
\hline Kindergarten experience & $\begin{array}{l}-0.0214^{*} \\
(0.0128)\end{array}$ & $\begin{array}{l}-0.0422^{*} \\
(0.0251)\end{array}$ & $\begin{array}{l}-0.0281 * * \\
(0.0124)\end{array}$ & $\begin{array}{l}-0.0554 * * \\
(0.0244)\end{array}$ \\
\hline Han ethnicity & $\begin{array}{l}-0.1831^{* *} \\
(0.0712)\end{array}$ & $\begin{array}{l}-0.1977 * * \\
(0.0768)\end{array}$ & $\begin{array}{l}-0.0390 \\
(0.0689)\end{array}$ & $\begin{array}{l}-0.0421 \\
(0.0744)\end{array}$ \\
\hline Number of siblings & $\begin{array}{l}0.2034 * * * \\
(0.0695)\end{array}$ & $\begin{array}{l}0.1797 * * * \\
(0.0614)\end{array}$ & $\begin{array}{l}0.1149 * \\
(0.0675)\end{array}$ & $\begin{array}{l}0.1015 * \\
(0.0596)\end{array}$ \\
\hline Fathers' education & $\begin{array}{l}-0.0054 \\
(0.0338)\end{array}$ & $\begin{array}{l}-0.0068 \\
(0.0429)\end{array}$ & $\begin{array}{l}-0.0929 * * * \\
(0.0328)\end{array}$ & $\begin{array}{l}-0.1179 * * * \\
(0.0416)\end{array}$ \\
\hline Mothers' education & $\begin{array}{l}0.0118 \\
(0.0226)\end{array}$ & $\begin{array}{l}0.0163 \\
(0.0311)\end{array}$ & $\begin{array}{l}0.0073 \\
(0.0219)\end{array}$ & $\begin{array}{l}0.0100 \\
(0.0302)\end{array}$ \\
\hline Family income level & $\begin{array}{l}-0.0006 \\
(0.0141)\end{array}$ & $\begin{array}{l}-0.0013 \\
(0.0296)\end{array}$ & $\begin{array}{l}-0.0005 \\
(0.0137)\end{array}$ & $\begin{array}{l}-0.0010 \\
(0.0288)\end{array}$ \\
\hline Parental expectations & $\begin{array}{l}-0.0367 \\
(0.0326)\end{array}$ & $\begin{array}{l}-0.0420 \\
(0.0374)\end{array}$ & $\begin{array}{l}-0.0276 \\
(0.0316)\end{array}$ & $\begin{array}{l}-0.0316 \\
(0.0363)\end{array}$ \\
\hline Family material support & $\begin{array}{l}0.0048 \\
(0.0095)\end{array}$ & $\begin{array}{l}0.0115 \\
(0.0227)\end{array}$ & $\begin{array}{l}-0.0034 \\
(0.0093)\end{array}$ & $\begin{array}{l}-0.0080 \\
(0.0221)\end{array}$ \\
\hline School expenditure per student & $\begin{array}{l}-0.5257 * * * \\
(0.1617)\end{array}$ & $\begin{array}{l}-0.5516^{* * * *} \\
(0.1697)\end{array}$ & $\begin{array}{l}-0.6540 * * * \\
(0.1573)\end{array}$ & $\begin{array}{l}-0.6862 * * * \\
(0.1651)\end{array}$ \\
\hline Teacher quality & $\begin{array}{l}-0.0314 \\
(0.0385)\end{array}$ & $\begin{array}{l}-0.0440 \\
(0.0540)\end{array}$ & $\begin{array}{l}-0.0571 \\
(0.0374)\end{array}$ & $\begin{array}{l}-0.0800 \\
(0.0524)\end{array}$ \\
\hline School environment & $\begin{array}{l}0.1168 \\
(0.0840)\end{array}$ & $\begin{array}{l}0.1126 \\
(0.0810)\end{array}$ & $\begin{array}{l}0.1320 \\
(0.0815)\end{array}$ & $\begin{array}{l}0.1272 \\
(0.0786)\end{array}$ \\
\hline Student-teacher ratio & $\begin{array}{l}0.2597 \\
(0.2212)\end{array}$ & $\begin{array}{l}0.2746 \\
(0.2339)\end{array}$ & $\begin{array}{l}0.1800 \\
(0.2145)\end{array}$ & $\begin{array}{l}0.1904 \\
(0.2268)\end{array}$ \\
\hline Parental involvement & $\begin{array}{l}0.0238 \\
(0.0204)\end{array}$ & $\begin{array}{l}0.0327 \\
(0.0280)\end{array}$ & $\begin{array}{l}0.0116 \\
(0.0198)\end{array}$ & $\begin{array}{l}0.0160 \\
(0.0272)\end{array}$ \\
\hline Average level of parents' education & $\begin{array}{l}-0.0316 \\
(0.0577)\end{array}$ & $\begin{array}{l}-0.0221 \\
(0.0404)\end{array}$ & $\begin{array}{l}0.0122 \\
(0.0562)\end{array}$ & $\begin{array}{l}0.0085 \\
(0.0393)\end{array}$ \\
\hline Regional fixed effects & YES & YES & YES & YES \\
\hline School location fixed effects & YES & YES & YES & YES \\
\hline Observations & 6016 & 6016 & 6016 & 6016 \\
\hline
\end{tabular}

Standard errors clustered at school level are shown in parentheses

Significance codes: $* * * p<0.01, * * p<0.05$, and $* p<0.1$ 
Table 6 presents the coefficient differences of three-fold decomposition. Results using both groups as reference groups are reported. We focus on the role of family investment and school quality, and thus, we are only concerned with the differences in the marginal effects of family investment and school quality. From Table 6, we can see that almost all differences in the coefficients of family investment and school quality are insignificant, except for the school expenditures per student. The differences are significantly negative. This implies that migrant children benefit less than their rural counterparts from school investment. This may indicate the potential social exclusion of migrant children, to stop them from enjoying the full range of services in urban public schools. Such social exclusion may include hostile attitudes from native classmates and teachers (Xue 2018).

\section{Discussion}

In recent years, the number of migrant children in compulsory education has surpassed the number of children who were left behind (MOE 2018). This implies that evaluating whether and how family migration affects migrant children's educational performances is crucial in modern-day China.

Using data from the National Children's Study of China (NCSC), this study examines the effect of migration on children's human capital accumulation. The Oaxaca-Blinder decomposition method is also applied to analyze the contributors to the gains from family migration. Considering that family migration changes both the family and the school environment of children, we are especially concerned with the roles of family investments and school quality. These factors can also be manipulated by families and governments. We found that migrant children significantly outperform their rural counterparts in terms of Chinese and math test scores. The results of the OB decomposition method further show that family investment and school quality play the most important roles in shaping the gaps. Given the great rural-urban gap, our findings have important implications for the urbanization of China. The details are discussed as follows:

First, this article demonstrates that migration benefits migrant children's education. Our results are consistent with our intuition and some previous findings (Xu and Xie 2015; Chen and Feng 2019). These findings are also consistent with the prediction of the assimilation theory of sociology (Warner and Strole 1945) which states that migration will benefit migrants and their offspring. As a result, completely relaxing the Hukou system makes sense in terms of children's development and social mobility.

Second, this paper shows that changes in family investments contribute to children's performance. It is found that changes in family educational expectations and material supports are the two most important factors. Both of them account for over $40 \%$ of the total gaps. These findings are consistent with the literature such as Coleman (1968). In addition, the findings also demonstrate the family benefits of rural-urban migration in china.

Third, we find that school quality plays an important role in affecting migrant children's performance. The OB decomposition method shows that the four terms of school quality are all important elements of the gaps. Given the controversial report of Coleman (1968), our results highlight the importance of school investments to children's development.

Finally, our results may suggest potential social exclusions being practiced in urban public schools. In our coefficient decomposition, we can see that the difference between the coefficients of school expenditure per student is negative and significant (see Table 6). This may imply that migrant children cannot enjoy the full range of school services. The social exclusion may come from hostile attitudes of native classmeates and teachers (Xue 2018). Removing all potential social exclusions makes sense in improving migrant children's outcomes.

This article has two specific limitations. The first is that we can only calculate the contributions of some observed investments of family and schools. However, we cannot exclude other important family and school elements, such as parenting styles. Recent studies have shown that parenting styles affect the formation of children's preferences and choices, thereby affecting their educational achievements and future outcomes in the labor market (Dornbusch et al. 1987, Doepke and Zilibotti 2017; Doepke et al. 2019). However, we do not have the necessary information regarding parenting styles connected to children's educational outcomes. The Second is that we cannot make a causal inference from the findings, because family investments may be endogenous to children's outcomes. For example, parents usually have higher expectations for children who perform better in school. Future research should consider the causal relationship between parents' expectations and children's outcomes.

\section{Conclusion}

In recent years, the number of migrant children in compulsory education has surpassed the number of children who were left behind (MOE 2018). However, studies have released contradictory findings of the effects of migration on migrant children's outcomes (Xu and Xie 2015; Wang et al. 2017; Chen and Feng 2019). It is important to use a national and representative sample to reexamine this question. Using a unique and detailed psychological dataset from the National Children's Study of China (NCSC), this paper 
studies whether and how family migration affects children's academic achievements.

The major findings of this paper include three aspects. First, PSM estimates suggest that children's academic performances are significantly correlated to family migration. Second, the results of OB decomposition indicate that the family investments and school quality accounted for a major portion of the migration benefits, especially the family educational expectations. Finally, migrant children may encounter social exclusion in public schools in cities. The results suggest that generally speaking, migrant children can take advantage of family migration, mainly by acquiring additional opportunities for better family education and school quality.

There are three important policy implications for migrant children. First, continuing to relax rural-urban migration restrictions makes sense. Given our findings that migration can benefit migrant children's academic outcomes, encouraging family migration will help to narrow the rural-urban gap and promote upward social mobility. Second, giving migrant children more opportunities to attend urban public schools will better off migrant children. Given that migrant children in private schools perform worse than their rural counterparts (Wang et al. 2017), this article states that providing chances for migrant children to access to public schools in urban China is urgent. Finally, governments and public schools in cities should try their best to eliminate all potential social exclusions in schools exposed to migrant children.

Acknowledgements We acknowledge the support of National Natural Science Foundation of China (71403226), Humanities and Social Sciences Fund of the Ministry of Education of China (19YJC790071), Research Fund of Southwest University of Political Science and Law (2018XZQN-40) and Fundamental Research Funds for the Central Universities (JBK2001051). We also appreciate the data support of National Children's Study of China from Beijing Normal University.

\section{Appendix}

More details of the PSM are shown in Tables 7, 8, including first-stage regression results, results of different matching method and balancing tests.
Table 7 First-stage regression results of PSM

\begin{tabular}{ll}
\hline Variables & Coefficients \\
\hline Age & -0.0035 \\
Female & $(0.0032)$ \\
& $-0.0188^{*}$ \\
Educational stage & $(0.0098)$ \\
& $-0.1360^{* * *}$ \\
Kindergarten experience & $(0.0164)$ \\
& $0.0692^{* * *}$ \\
Han ethnicity & $(0.0121)$ \\
& $0.1036^{* * *}$ \\
Number of siblings & $(0.0137)$ \\
& $-0.0231^{* * *}$ \\
Father's education & $(0.0063)$ \\
& $0.0617^{* * *}$ \\
Mother's education & $(0.0115)$ \\
& 0.0059 \\
Regional fixed effects & $(0.0115)$ \\
School location fixed effects & YES \\
Constant & YES \\
Observations & $0.8216^{* * *}$ \\
R-squared & $(0.0401)$ \\
\hline
\end{tabular}

Robust standard errors are shown in parentheses

Significance codes: $* * * p<0.01, * * p<0.05$, and $* p<0.1$

Table 8 Results of PSM using different matching method

\begin{tabular}{lcc}
\hline Matching method & Chinese & Mathematics \\
\hline Local linear regression & $0.2235^{* * *}$ & $0.1582^{* * *}$ \\
& $(0.0481)$ & $(0.0417)$ \\
Kernel & $0.2404 * * *$ & $0.1698 * * *$ \\
& $(0.0382)$ & $(0.0381)$ \\
One to one & $0.2108^{* * *}$ & $0.1724 * * *$ \\
& $(0.0487)$ & $(0.0675)$ \\
Radius & $0.1106 * * *$ & $0.1540 * * *$ \\
& $(0.0505)$ & $(0.0581)$ \\
\hline
\end{tabular}

Standard errors from bootstrapping 200 times are shown in parentheses. The bandwidths of the local linear regression matching and kernel matching and calipers of one-one matching and radius matching are all set to 0.001

Significance codes: $* * * p<0.01, * * p<0.05$, and $* p<0.1$ 
Table 9 Results of covariate imbalance testing of PSM

\begin{tabular}{llccc}
\hline Variables & Matching status & Treated & Control & $\begin{array}{c}\text { Statistics } \\
\text { of T test }\end{array}$ \\
\hline Age & Unmatched & 12.0300 & 11.1320 & $13.3^{* * *}$ \\
& Matched & 12.0140 & 11.9690 & 0.77 \\
Female & Unmatched & 0.4591 & 0.4136 & $3.43^{* * *}$ \\
& Matched & 0.4575 & 0.4622 & -0.41 \\
Educational stage & Unmatched & 0.4377 & 0.2780 & $12.45^{* * *}$ \\
\multirow{3}{*}{ Kindergarten experience } & Matched & 0.4338 & 0.4267 & 0.63 \\
& Unmatched & 0.2318 & 0.4563 & $-18.58^{* * *}$ \\
Han ethnicity & Matched & 0.2334 & 0.2364 & -0.31 \\
& Unmatched & 0.8515 & 0.9190 & $-7.69 * * *$ \\
Number of siblings & Matched & 0.8573 & 0.8691 & -1.5 \\
& Unmatched & 2.2067 & 1.9495 & $11.49 * * *$ \\
Father's education & Matched & 2.1967 & 2.1944 & 0.12 \\
\multirow{2}{*}{ Mother's education } & Unmatched & 0.5851 & 0.7425 & $-12.42^{* * *}$ \\
& Matched & 0.5891 & 0.5908 & -0.15 \\
& Unmatched & 0.4141 & 0.5714 & $-11.91 * * *$ \\
\hline
\end{tabular}

Significance codes: $* * * p<0.01, * * p<0.05$, and $* p<0.1$

\section{References}

Becker, G. S., \& Lewis, H. G. (1973). On the Interaction between the quantity and quality of children. Journal of Political Economy, 81(2), S279-S288.

Blinder, A. S. (1973). Wage discrimination: Reduced form and structural estimates. The Journal of Human Resources 8(4), 436.

Black, S. E., Devereux, P. J., \& Salvanes, K. G. (2005). Why the apple doesn't fall far: Understanding intergenerational transmission of human capital. American Economic Review, 95(1), 437-449.

Black, S. E., Devereux, P. J., \& Salvanes, K. G. (2009). Like father, like son? A note on the intergenerational transmission of IQ scores. Economics Letters, 105(1), 138-140.

Chan, K. W., \& Buckingham, W. (2008). Is China abolishing the Hukou system? China Quarterly, 195, 582-606.

Chen, Y., \& Feng, S. (2019). The education of migrant children in China's urban public elementary schools: Evidence from Shanghai. China Economic Review, 54, 390-402.

Chen, Y., Feng, S., \& Han, Y. (2019). Research on the education of migrant children in China: A review of the literature. Frontiers of Economics in China, 14(2), 168-202.

Coleman, J. S. (1968). Equality of educational opportunity. Equity \& Excellence in Education, 6(5), 19-28.

Cunha, F., \& Heckman, J. J. (2009). The economics and psychology of inequality and human development. Journal of the European Economic Association, 7(2-3), 320-364.

Cunha, F., Heckman, J. J., Locher, L., \& Masterov, D. V. (2006). Interpreting the evidence on life cycle skill formation. In E. A. Hanushek \& F. Welch (Eds.), Handbook of the economics of Education (Vol. 1, pp. 697-812). Amsterdam: Elsevier.

Davis-Kean, P. E. (2005). The influence of parent education and family income on child achievement: The indirect role of parental expectations and the home environment. Journal of family psychology, 19(2), 294-304.

Doepke, M., \& Zilibotti, F. (2017). Parenting with style: Altruism and paternalism in intergenerational preference transmission. Econometrica, 85(5), 1331-1371.
Doepke, M., Sorrenti, G., \& Zilibotti, F. (2019). The economics of parenting. Annual Review of Economics, 11, 55-84.

Duncan, G. J., \& Magnuson, K. A. (2005). Can family socioeconomic resources account for racial and ethnic test score gaps? The Future of Children, 15(1), 35-54.

Dornbusch, S. M., Ritter, P. L., Leiderman, P. H., Roberts, D. F., \& Fraleigh, M. J. (1987). The relation of parenting style to adolescent school performance. Child Development, 58(95), 1244-1257.

Fan, X., \& Chen, M. (2001). Parental involvement and students' academic achievement: A meta-analysis. Educational Psychology Review, 13(1), 1-22.

Hanushek, E. A., \& Woessmann, L. (2008). The role of cognitive skills in economic development. Journal of economic literature, 46(3), 607-668.

Heckman, J. J., Stixrud, J., \& Urzua, S. (2006). The effects of cognitive and noncognitive abilities on labor market outcomes and social behavior. Journal of Labor Economics, 24(3), 411-482.

Heyneman, S. P., \& Loxley, W. A. (1983). The effect of primary-school quality on academic achievement across twenty-nine high-and low-income countries. American Journal of sociology, 88(6), $1162-1194$.

Lai, F., Liu, C., Luo, R., Zhang, L., Ma, X., Bai, Y., et al. (2014). The education of China's migrant children: The missing link in China's education system. International Journal of Educational Development, 37, 68-77.

Lu, Y. (2012). Education of children left behind in rural China. Journal of Marriage and Family, 74(2), 328-341.

Lv, L., \& Wang, F. (2017). Migration and children's education: Facts and explanations (Chinese). Population Research, 41(6), 45-57.

Ministry of Education of China. (2018). Statistical report of the development of national education in 2017. Beijing: Ministry of Education of the PRC.

Oaxaca, R. (1973). Male-female wage differentials in urban labor markets. International Economic Review, 14(3), 693.

Portes, A., \& Zhou, M. (1993). The new second generation: Segmented assimilation and its variants. Annals of the American Academy of Political \& Social Science, 530, 74-96. 
Potochnick, S. (2014). The academic adaptation of children of immigrants in new and established settlement states: The role of family, schools, and neighborhoods. Population research and policy review, 33(3), 335-364.

Rosenbaum, P. R., \& Rubin, D. B. (1983). The central role of the propensity score in observational studies for causal effects. Biometrika, 70(1), 41-55.

Smith, J. A., \& Todd, P. E. (2005). Does matching overcome LaLonde's critique of nonexperimental estimators? Journal of Econometrics, 125(1-2), 305-353.

Van de Poel, E., \& Speybroeck, N. (2009). Decomposing malnutrition inequalities between scheduled castes and tribes and the remaining indian population. Ethnicity \& Health, 14(3), 271-287.

Wang, F. (2000s). Reformed migration control and new targeted people: China's Hukou system in the 2000s. The China Quarterly, 177, 115-132.

Wang, X., Luo, R., Zhang, L., \& Rozelle, S. (2017). The education gap of China's migrant children and rural counterparts. Journal of Development Studies, 53(11), 1865-1881.

Warner, W. L., \& Srole, L. (1945). The social systems of American ethnic groups. New Haven, CT: Yale University Press.

Wu, X., \& Treiman, D. J. (2004). The household registration system and social stratification in China: 1955-1996. Demography, 41, 363-384.
Xie, Y., \& Greenman, E. (2011). The social context of assimilation: Testing implications of segmented assimilation theory. Social Science Research, 40, 965-984.

$\mathrm{Xu}, \mathrm{H} .$, \& Xie, Y. (2015). The causal effects of rural-to-urban migration on children's well-being in China. European Sociological Review, $31(4), 502-519$.

Xue, S. (2018). Does contact improve attitudes towards migrants in China? Evidence from urban residents. Economics of Transition, 26(2), 149-200.

Yang, D. (2017). Annual report on education for China's migrant children in 2016 (in Chinese). Beijing: Social Science Academic Press.

Zhao, G., Ye, J., Li, Z., \& Xue, S. (2017). How and why do Chinese urban students outperform their rural counterparts? China Economic Review, 45, 103-123.

Zhao, Y. (1999). Leaving the countryside: Rural-to-urban migration decisions in China. American Economic Review, 89(2), 281-286.

Zhou, M. (1997). Growing up American: The challenge confronting immigrant children and children of immigrants. Annual Review of Sociology, 23, 63-95.

Publisher's Note Springer Nature remains neutral with regard to jurisdictional claims in published maps and institutional affiliations. 